\title{
Longitudinal surface structures (flowstripes) on Antarctic glaciers
}

\author{
N. F. Glasser ${ }^{1}$ and G. H. Gudmundsson ${ }^{2}$ \\ ${ }^{1}$ Centre for Glaciology, Institute of Geography and Earth Sciences, Aberystwyth University, SY23 3DB, Wales, UK \\ ${ }^{2}$ British Antarctic Survey, High Cross, Madingley Road,Cambridge, CB3 OET, England, UK
}

Correspondence to: N. F. Glasser (nfg@ aber.ac.uk)

Received: 25 October 2011 - Published in The Cryosphere Discuss.: 3 November 2011

Revised: 20 March 2012 - Accepted: 24 March 2012 - Published: 30 March 2012

\begin{abstract}
Longitudinal surface structures ("flowstripes") are common on many glaciers but their origin and significance are poorly understood. In this paper we present observations of the development of these longitudinal structures from four different Antarctic glacier systems; the Lambert Glacier/Amery Ice Shelf area, the Taylor and Ferrar Glaciers in the Ross Sea sector, Crane and Jorum Glaciers (ice-shelf tributary glaciers) on the Antarctic Peninsula, and the onset zone of a tributary to the Recovery Glacier Ice Stream in the Filchner Ice Shelf area. Mapping from optical satellite images demonstrates that longitudinal surface structures develop in two main situations: (1) as relatively wide flow stripes within glacier flow units and (2) as relatively narrow flow stripes where there is convergent flow around nunataks or at glacier confluence zones. Our observations indicate that the confluence features are narrower, sharper, and more clearly defined features. They are characterised by linear troughs or depressions on the ice surface and are much more common than the former type. Longitudinal surface structures within glacier flow units have previously been explained as the surface expression of localised bed perturbations but a universal explanation for those forming at glacier confluences is lacking. Here we propose that these features are formed at zones of ice acceleration and extensional flow at glacier confluences. We provide a schematic model for the development of longitudinal surface structures based on extensional flow that can explain their ridge and trough morphology as well as their down-ice persistence.
\end{abstract}

\section{Introduction}

The aim of this paper is to present observations of longitudinal surface structures on a number of different Antarctic glaciers from detailed mapping of the surface structures visible in remotely sensed images. Data are presented from four geographical areas of Antarctica; the Lambert
Glacier/Amery Ice Shelf area (the largest glacier in the world, draining $\sim 8 \%$ of Antarctica), the Ferrar and Taylor Glaciers (outlet glaciers in the Ross Sea sector), Crane and Jorum Glaciers (ice-shelf tributary glaciers) on the Antarctic Peninsula, and from the onset zone of a tributary to the Recovery Glacier Ice Stream in the Filchner Ice Shelf area (Fig. 1).

\subsection{Longitudinal structures: previous descriptions}

Longitudinal structures can be identified on the surface of many glaciers worldwide. They occur at the $\mathrm{km}$-scale on valley glaciers to tens or even hundreds of km in length on icesheet outlet glaciers in Greenland and Antarctica and on ice shelves. In the Antarctic context, longitudinal surface structures have been referred to previously as "flow stripes", "flow bands", "flow lines" or "streaklines" (Crabtree and Doake, 1980; Reynolds and Hambrey, 1988; Swithinbank et al. 1988; Casassa and Brecher, 1993; Casassa et al., 1991; Gudmundsson et al., 1998; Jacobel et al., 1993, 1999; Fahnestock et al., 2000; Hulbe and Fahnestock, 2004, 2007) (Table 1).

One of the most striking attributes of these features is their down-ice persistence. In the absence of any downstream overprinting, longitudinal surface structures can persist for long distances. In their structural analysis of the former Larsen B Ice Shelf, Glasser and Scambos (2008) noted that longitudinal surface structures on tributary glaciers and their ice-shelf continuations can be traced for distances of $>100 \mathrm{~km}$.

Field investigations on valley glaciers in Norway, Svalbard and the European and New Zealand Alps have demonstrated that these longitudinal surface structures are typically three-dimensional in nature (Hambrey, 1975, 1977; Hambrey and Glasser, 2003; Goodsell et al., 2005; Appleby et al., 2010). Where field relationships have been used to establish a three-dimensional nature, these features have been termed longitudinal foliation. 


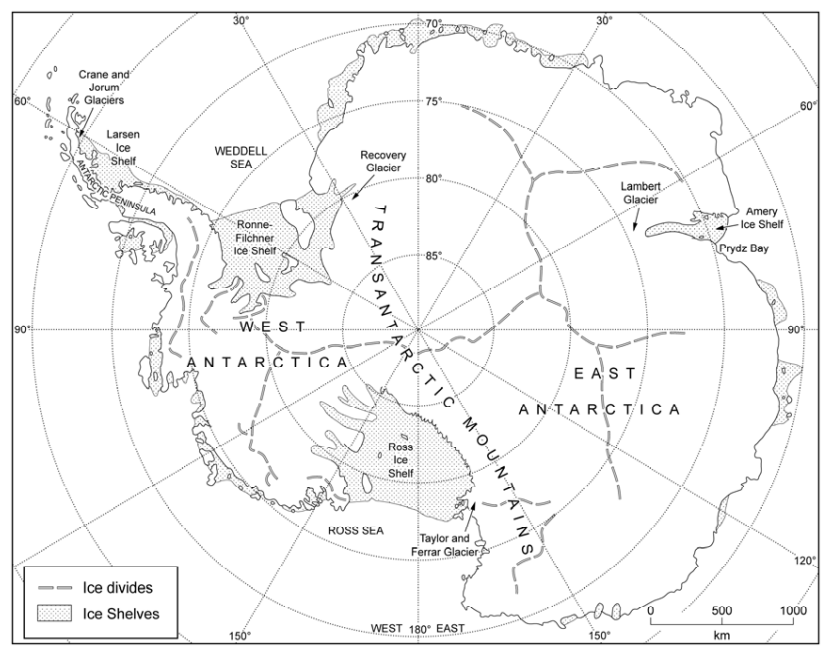

Fig. 1. Map of Antarctica showing locations of glaciers studied in this paper.

\subsection{Longitudinal structures: previous interpretations}

Longitudinal structures are commonly developed parallel to the margins of individual glacier flow units and are therefore inferred to represent relict or contemporary flow lines within an ice sheet (Table 1). However, the physical explanation for the origin of these longitudinal surface structures is unclear. Merry and Whillans (1993) considered that these features form in relation to localised high shear strain rates in ice streams near their onset areas. Another possibility is that they represent "shear zones" within individual flow units (Raymond, 1996). However, Casassa and Brecher (1993) found no velocity discontinuities across the boundaries between individual "flow stripes" on the Byrd Glacier, which suggests that their persistence cannot be explained by lateral shear between the stripes.

It has also been suggested that flowstripes are the surface expression of vertical sheets of changed ice fabric (Whillans and Van der Veen, 1997; Hulbe and Whillans, 1997). These authors argued that flowstripes are represented by narrow vertical sheets or bands where the c-axis is oriented perpendicular to ice flow. Their analysis indicates that crystals are aligned such that the bands are weaker to transverse compression and stronger to lateral shear. The shearing rate is at least two times slower and the transverse compression is at least two times faster in the bands than the surrounding ice (Hulbe and Whillans, 1997).

Another possible explanation is that these structures are created by the visco-plastic deformation or folding of preexisting inhomogeneities, such as primary stratification, under laterally compressive and longitudinally tensile stresses (Hambrey, 1977; Hooke and Hudleston, 1978). Longitudinal structures may also form as ice flows over a localized bedrock undulation when the flow is characterized by high rates of basal motion as compared to rates of internal ice deformation (Gudmundsson et al., 1998). Their model experiments suggest that longitudinal surface structures form under conditions of rapid basal sliding and persist as surface features for several hundred years after rapid sliding has stopped (Gudmundsson et al., 1998). They concluded that ice streams act as band-pass filters passing basal undulations of wavelengths few times the ice thickness almost perfectly to the surface, while suppressing both smaller and larger wavelengths.

A "streakline", as defined in continuum mechanics, is the set of all material particles that have passed through a particular spatial point at some time in the past. In this paper we use the term "flowstripe" to collectively describe the longitudinal surface features we observe. As shown below, our analysis indicates that flowstripes are particular forms of streaklines.

From this brief review of the literature on longitudinal surface structures we identify three possible explanations for the formation of these features. These can be summarised as follow:

1. They form as a result of lateral compression in topographic situations where glaciers flow from wide accumulation basins into a narrow tongue. In this case the longitudinal surface structures would be the surface expression of three-dimensional folding within the ice under strong lateral compression (i.e. a longitudinal foliation). We would therefore expect longitudinal surface structures to be concentrated in areas where multiple accumulation basins feed single glacier tongues.

2. They form where two glacier tributaries, possibly flowing at different velocities, converge and are therefore associated with shear margins between individual flow units. In this case we would expect the longitudinal surface structures to be concentrated at the boundaries between individual flow units.

3. They are the surface expression of subglacial bed perturbations created during rapid basal sliding. In this case the longitudinal surface structures represent features transmitted to the ice surface by flow across an irregular subglacial topography. We would therefore expect there to be little or no relationship between the configuration of individual flow units and the development of longitudinal surface structures. Instead we would expect these structures simply to reflect rapid ice-flow across rough glacier beds.

\section{Methods}

Mapping of ice-surface features was conducted in ArcMap GIS software using optical satellite images from Landsat 7 ETM+ and Terra ASTER. Image acquisition dates used 
Table 1. Previously reported terminology and characteristics of longitudinal surface structures on Antarctic glaciers and ice shelves.

\begin{tabular}{|c|c|c|c|}
\hline Terminology & Characteristics & Origin/interpretation & Reference \\
\hline $\begin{array}{l}\text { "Lineations"; } \\
\text { forming "flow } \\
\text { lines" }\end{array}$ & $\begin{array}{l}\text { Undulating surface ridges and } \\
\text { troughs parallel to ice flow. }\end{array}$ & Unspecific. & Crabtree and Doake (1980) \\
\hline $\begin{array}{l}\text { "Longitudinal } \\
\text { foliation" }\end{array}$ & $\begin{array}{l}\text { Longitudinal structure parallel to } \\
\text { flow lines. }\end{array}$ & $\begin{array}{l}\text { Surface expression of three- } \\
\text { dimensional structures } \\
\text { including large-scale isoclinal } \\
\text { folding of primary } \\
\text { stratification. }\end{array}$ & $\begin{array}{l}\text { Reynolds and Hambrey } \\
\text { (1988) }\end{array}$ \\
\hline "Flow bands" & $\begin{array}{l}\text { Can be tracked without a break } \\
\text { from their ice-stream source to the } \\
\text { ice front over distances of } 800 \mathrm{~km} \text {. }\end{array}$ & $\begin{array}{l}\text { "Flow bands" originate from } \\
\text { ice streams, but no specific } \\
\text { mechanism provided. }\end{array}$ & Swithinbank et al. (1988) \\
\hline "Flow stripes" & $\begin{array}{l}\text { Appear as curvilinear bands of } \\
\text { contrasting brightness on satellite } \\
\text { images. Topographic flow stripes } \\
\text { are associated with ridge and } \\
\text { trough topography with double } \\
\text { amplitudes of } 7 \text { to } 45 \mathrm{~m} \text { and slopes } \\
\text { of } 1-7 \% \text {. Textural flow stripes } \\
\text { correspond to bands of distinct } \\
\text { crevasse patterns. }\end{array}$ & $\begin{array}{l}\text { No velocity discontinuities } \\
\text { across the boundaries of flow } \\
\text { stripes so down-ice } \\
\text { persistence is not explained } \\
\text { by lateral shear between flow } \\
\text { stripes. } \\
\text { Flow stripes may represent } \\
\text { relict flowlines. }\end{array}$ & $\begin{array}{l}\text { Casassa and Brecher (1993); } \\
\text { Casassa et al. (1991) }\end{array}$ \\
\hline "Flow traces" & $\begin{array}{l}\text { Flow traces originating from former } \\
\text { shear margins. }\end{array}$ & $\begin{array}{l}\text { Localised high shear strain rates } \\
\text { in ice streams near their onset } \\
\text { areas and in "sticky spots". }\end{array}$ & Merry and Whillans (1993) \\
\hline "Foliation" & $\begin{array}{l}\text { Longitudinal structure developed } \\
\text { parallel to margins of flow units, } \\
\text { May also be parallel to medial } \\
\text { moraines. Can be used to define } \\
\text { contributions from individual flow } \\
\text { units. }\end{array}$ & $\begin{array}{l}\text { Surface expression of three- } \\
\text { dimensional structures. } \\
\text { Represents deformation or } \\
\text { folding of pre-existing } \\
\text { inhomogeneities under } \\
\text { laterally compressive and } \\
\text { longitudinally tensile stresses. }\end{array}$ & $\begin{array}{l}\text { Hambrey and } \\
\text { Dowdeswell (1994) }\end{array}$ \\
\hline $\begin{array}{l}\text { "Bands of } \\
\text { aligned- } \\
\text { crystal ice" }\end{array}$ & $\begin{array}{l}\text { Occur in areas of considerable } \\
\text { surface relief (peak to trough vertical } \\
\text { distances of } 30 \mathrm{~m} \text { over } 10 \mathrm{~km} \text { ). }\end{array}$ & $\begin{array}{l}\text { Longitudinal bands are the } \\
\text { surface expression of vertical } \\
\text { sheets of changed ice fabric. }\end{array}$ & Hulbe and Whillans (1997) \\
\hline "Flow stripes" & No description-modelling study. & $\begin{array}{l}\text { Generated from basal } \\
\text { irregularities whenever } \\
\text { velocity at the bed is large } \\
\text { compared to ice thickness. }\end{array}$ & Gudmundsson et al. (1998) \\
\hline "Flow stripes" & $\begin{array}{l}\text { Surface topographic ridges or } \\
\text { troughs with metre-scale relief, } \\
\text { hundreds of metres to } \mathrm{km} \text { in width, } \\
\text { tens to hundreds of } \mathrm{km} \text { in length. }\end{array}$ & $\begin{array}{l}\text { Formed in outlet glaciers and } \\
\text { ice streams then advected } \\
\text { down-ice. Indicate flow from } \\
\text { a localised source. }\end{array}$ & Fahnestock et al. (2000) \\
\hline "Streaklines" & $\begin{array}{l}\text { Downstream-trending subtle ridges } \\
\text { in surface elevation. Can be traced } \\
\text { over hundreds of } \mathrm{km} \text {. }\end{array}$ & $\begin{array}{l}\text { Originate in the grounded ice } \\
\text { sheet, where ice flows over a } \\
\text { basal disturbance. }\end{array}$ & $\begin{array}{l}\text { Hulbe and Fahnestock } \\
(2004,2007)\end{array}$ \\
\hline "Flow stripes" & $\begin{array}{l}\text { Surface undulations with } \\
\text { kilometre-scale spacing } \\
\text { and metre-scale relief. }\end{array}$ & $\begin{array}{l}\text { Indicate fast ice flow; } \\
\text { modified by surface (aeolian) } \\
\text { processes during transport. }\end{array}$ & Campbell et al. (2008) \\
\hline "Flow stripes" & $\begin{array}{l}\text { Curvilinear stripes and crevasse } \\
\text { bands up to } 200 \mathrm{~km} \text { in length. }\end{array}$ & Relict flowlines. & Wuite and Jezek (2009) \\
\hline "Streaklines" & $\begin{array}{l}\text { Elongate furrows and ridges with } \\
\text { amplitude of typically } 1-2 \mathrm{~m} \text { and } \\
\text { spacing on the order of } 1 \mathrm{~km} \text {. }\end{array}$ & $\begin{array}{l}\text { Created when grounded ice } \\
\text { flows over irregular features } \\
\text { in the bed. }\end{array}$ & Raup et al. (2005) \\
\hline
\end{tabular}




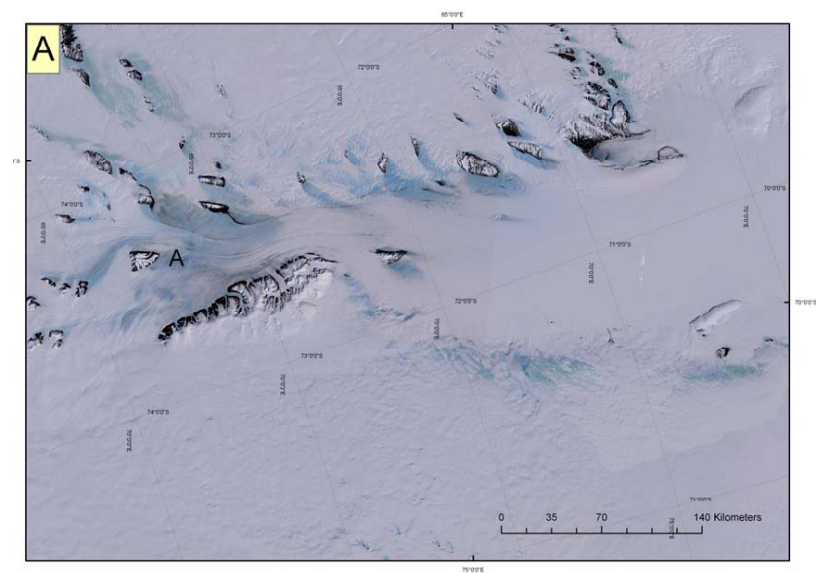

Fig. 2a. Mosaic of four Landsat images from LIMA of the Lambert Glacier/Amery Ice Shelf System.

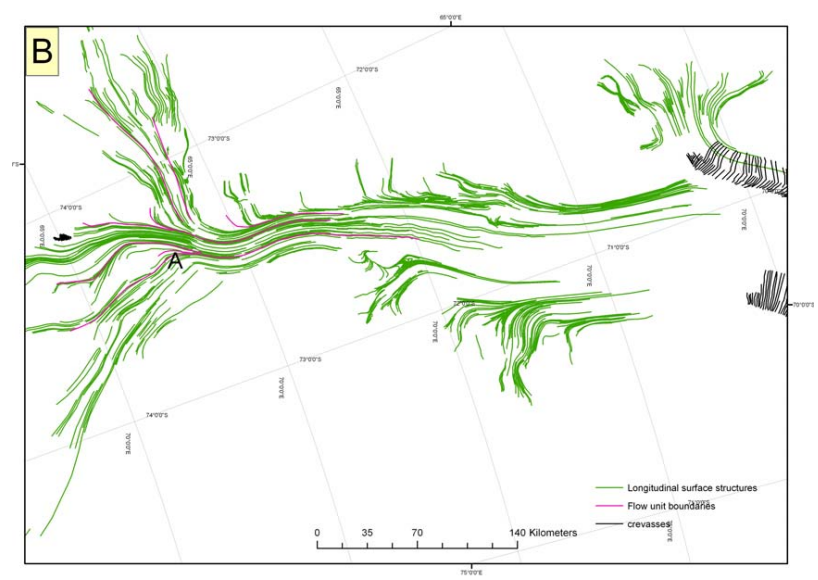

Fig. 2b. Interpretation of longitudinal surface structures. Point A indicates development of longitudinal surface structures at the boundary between individual flow units.

in this study are ASTER granules acquired on 22 November 2001; and Landsat 7 scenes acquired from the LIMA website (http://lima.usgs.gov/). Features mapped on the contemporary ice surface include longitudinal surface structures and associated surface debris, together with open crevasses (where present). Satellite image interpretation was performed using multiple band combinations and standard image enhancement procedures (contrast stretching and histogram equalization) to improve the contrast across the ice surface. The horizontal resolution of the satellite images is $15 \mathrm{~m}$ for both the Landsat 7 ETM+ panchromatic band (Band 8) and the ASTER band $3 \mathrm{~N}$. Detailed mapping was carried out by on-screen digitizing of features in ArcMap at 1:50000 scale.

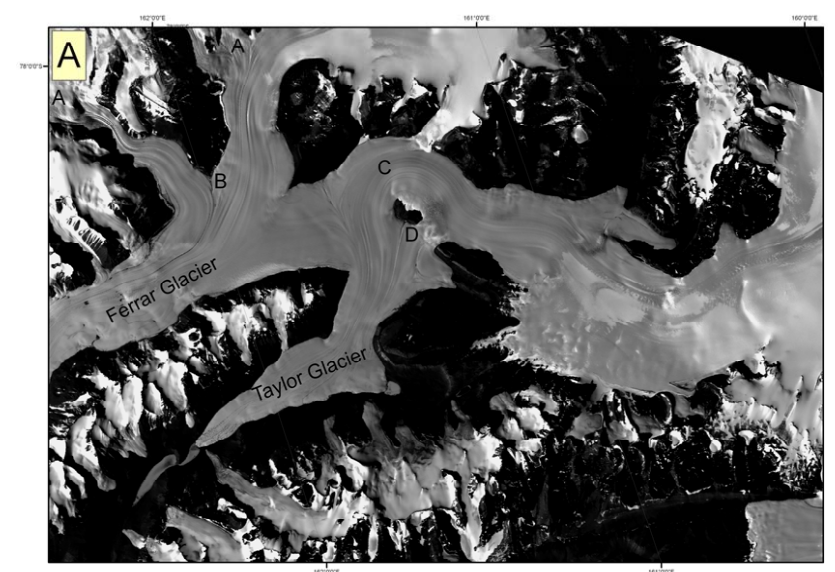

Fig. 3a. Portion of LIMA Landsat image LE705911 showing Taylor and Ferrar Glaciers in the Ross Sea area of Antarctica.

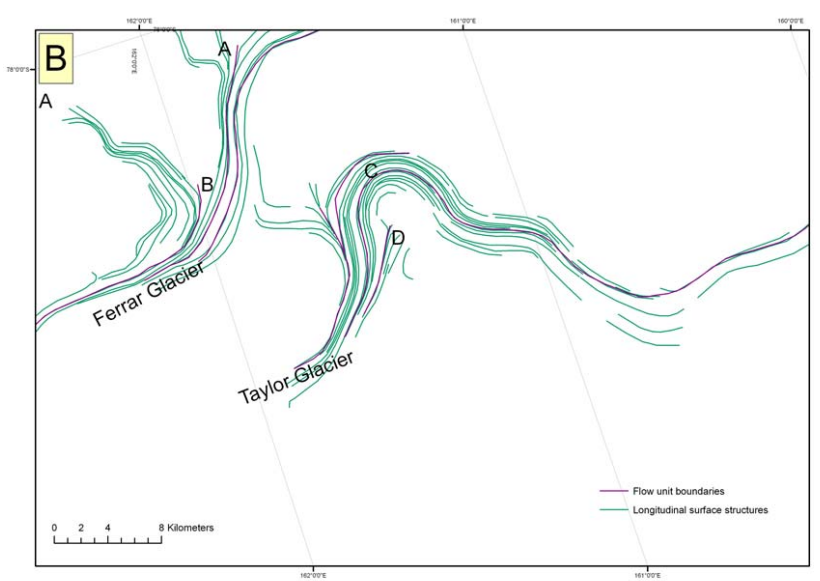

Fig. 3b. Interpretation of key surface structures. Point A indicates development of longitudinal surface structures in the accumulation area of the glacier. Point $\mathrm{B}$ indicates the zone where two individual outlet glaciers converge, and Point $\mathrm{C}$ indicates uninterrupted and persistent longitudinal surface structures where an outlet glacier turns sharply around a bedrock obstacle. Point D indicates development of longitudinal surface structures where two glaciers converge around a bedrock obstacle.

\subsection{Longitudinal surface structures on Antarctic glaciers}

The Lambert Glacier/Amery Ice Shelf area (Fig. 2): longitudinal surface structures dominate the glacier surface along almost its entire length. These surface structures are especially prominent at the boundary between individual flow units (e.g. Point A on Fig. 2), although they are also developed downstream of nunataks and bedrock ridges. Longitudinal surface structures are also developed at the glacier margins, where they appear to develop abruptly at points wherever there is mass input from the surrounding valley sides. In all cases, shadows on the ice surface indicate that depressions 


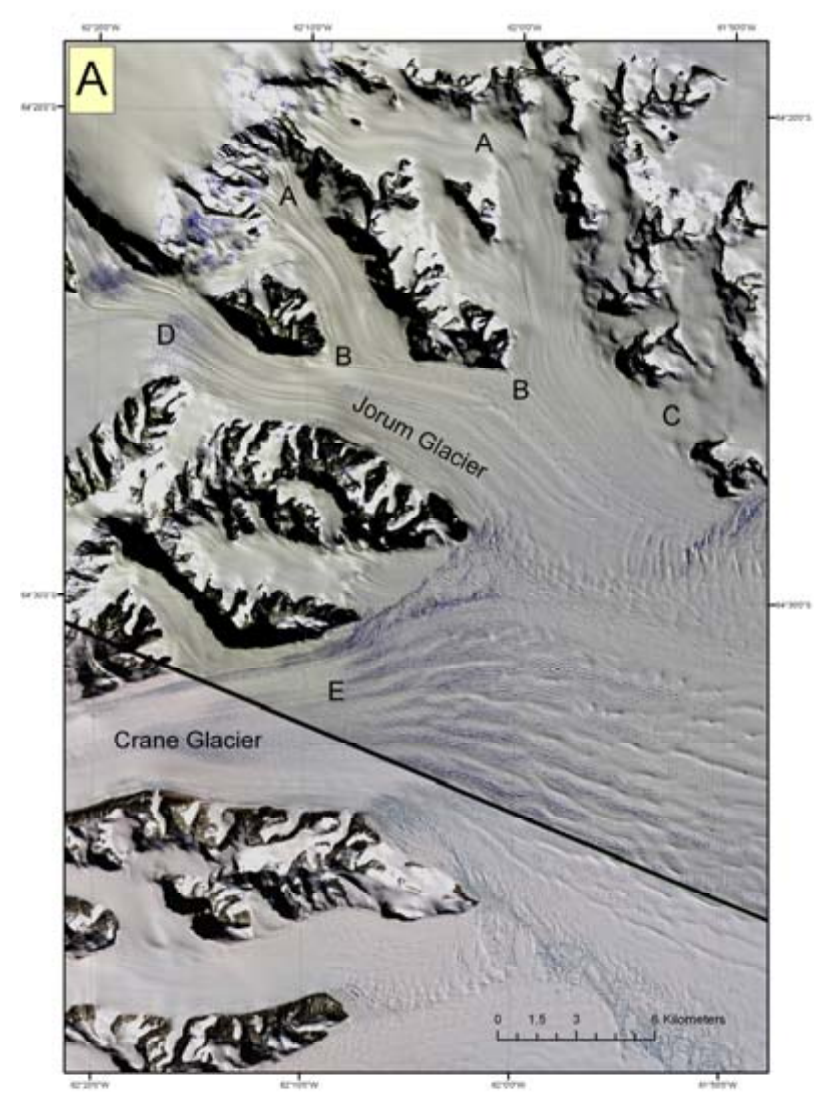

Fig. 4a. Portion of ASTER image from November 2001 showing Crane and Jorum Glaciers on the eastern side of the Antarctic Peninsula flowing into the former Larsen B Ice Shelf prior to its rapid disintegration in February-March 2002.

occur on the ice surface parallel to these longitudinal surface structures. Their vertical dimension is difficult to estimate but is probably of the order of $\sim 10 \mathrm{~m}$ at flow-unit boundaries, falling to $1 \mathrm{~m}$ over the Amery Ice Shelf, and finally to zero where obscured by snow on the ice-shelf surface near its calving front.

Outlet glaciers in the Ross Sea sector (Fig. 3): Taylor Glacier and Ferrar Glaciers flow into the Dry Valleys area of the Ross Sea area of Antarctica. Here, longitudinal surface structures are developed near cirque headwalls at the upstream confluence of individual outlet glaciers (e.g. Point A on Fig. 3), and in zones where larger outlet glaciers converge (e.g. Point B on Fig. 3). These structures remain uninterrupted and persistent even where Taylor Glacier turns sharply around the bedrock topography (e.g. Point $\mathrm{C}$ on Fig. 3). Again, shadows on the ice surface indicate that depressions occur on the ice surface along these longitudinal surface structures. Their vertical dimension is again difficult to estimate but is probably of the order of $\sim 10 \mathrm{~m}$ at flow-unit boundaries, falling to $1 \mathrm{~m}$ near the glacier snout.

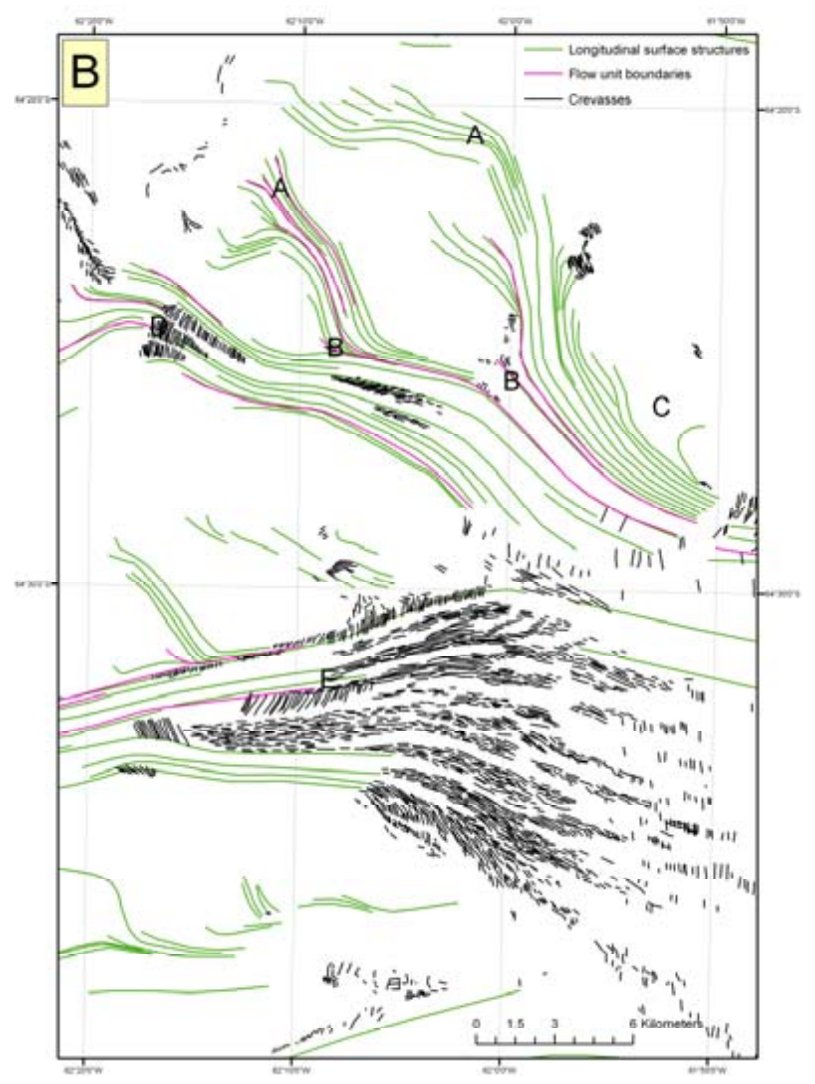

Fig. 4b. Interpretation of key surface structures. Point A indicates areas where longitudinal surface structures are developed immediately below cirque headwalls. Point B indicates the development of longitudinal surface structures where two large outlet glaciers converge. Point $C$ indicates development of longitudinal surface structures at glacier margins. Point D indicates persistence of longitudinal surface structures through a crevassed zone. Point E shows rapid truncation of longitudinal surface structures where crevasses are initiated at the grounding line of the ice shelf.

Crane and Jorum Glaciers (Fig. 4): these two glaciers on the eastern side of the Antarctic Peninsula flowed into the former Larsen B Ice Shelf prior to its rapid disintegration in February-March 2002. Longitudinal surface structures are developed immediately below cirque headwalls (e.g. Point A on Fig. 4), where large outlet glaciers converge (e.g. Point B on Fig. 4), and at glacier margins (e.g. Point C on Fig. 4). Longitudinal surface structures can persist through heavily crevassed zones (e.g. Point D on Fig. 4) but are rapidly truncated where crevasses are initiated at the grounding line of the ice shelf (e.g. Point E on Fig. 4).

The onset zone of a tributary of the Recovery Glacier Ice Stream, which feeds directly into the Filchner Ice Shelf (Fig. 5): longitudinal surface structures are persistent along the length of the glacier, although interrupted in places by crevassed zones (e.g. Point A on Fig. 5), and are present in sections where there is both convergent flow (Point B on 


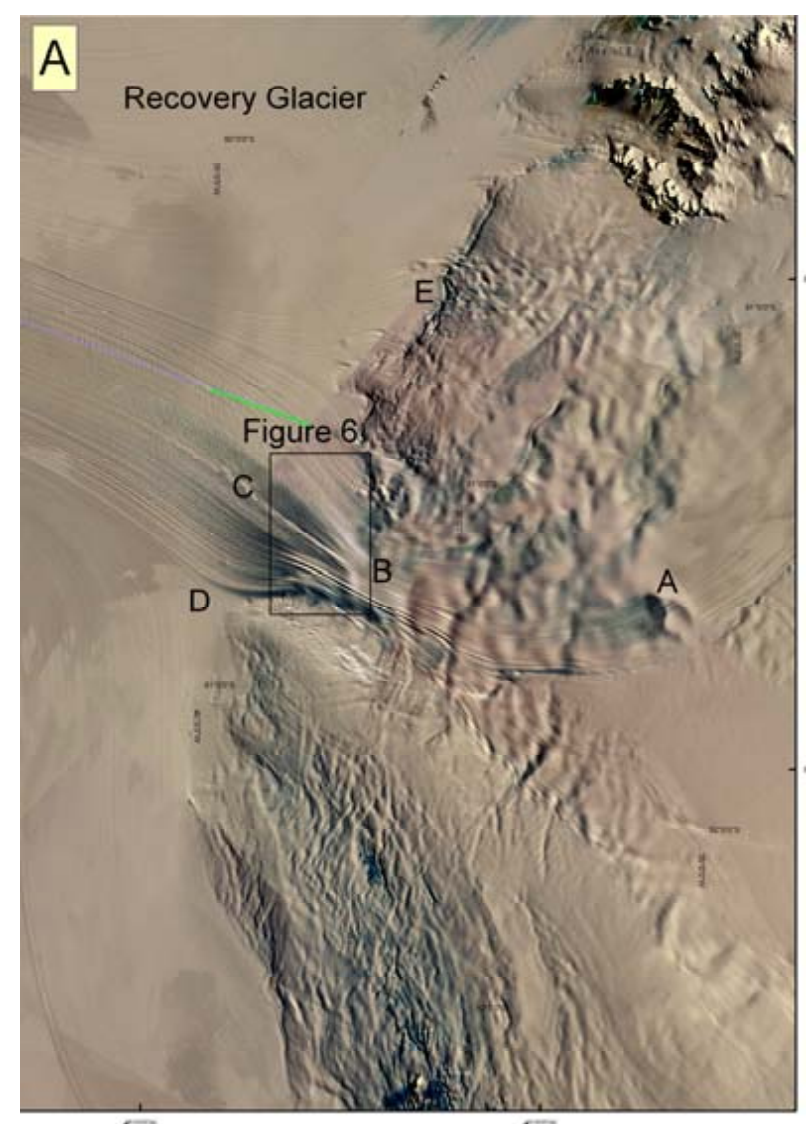

Fig. 5a. Portion of Landsat image from LIMA showing tributary glacier to Recovery Glacier as it enters the Filchner Ice Shelf.

Fig. 5) and divergent flow (Point $\mathrm{C}$ on Fig. 5). Longitudinal surface structures are also present where glaciers converge (Point D on Fig. 5). There is also evidence that these structures develop at the base of icefalls (Point E on Fig. 5). Close-up images of the longitudinal surface structures show that they have a pronounced ridge and trough morphology, with depressions or hollows forming on the ice surface parallel to the longitudinal surface structures (Fig. 6). We estimate a vertical dimension of the order of $\sim 10 \mathrm{~m}$ for these features.

\section{Summary of key observations}

We make the following generic statements concerning the occurrence of longitudinal surface structures on the glaciers studied.

1. Longitudinal surface structures are common features on Antarctic glaciers. These features can be observed at a range of spatial scales, from entire glacier catchments (Fig. 2) to individual valley glaciers (Fig. 3). They appear on ice-shelf tributary glaciers (Fig. 4) as well as the onset zones of fast-flowing ice streams (Fig. 5).

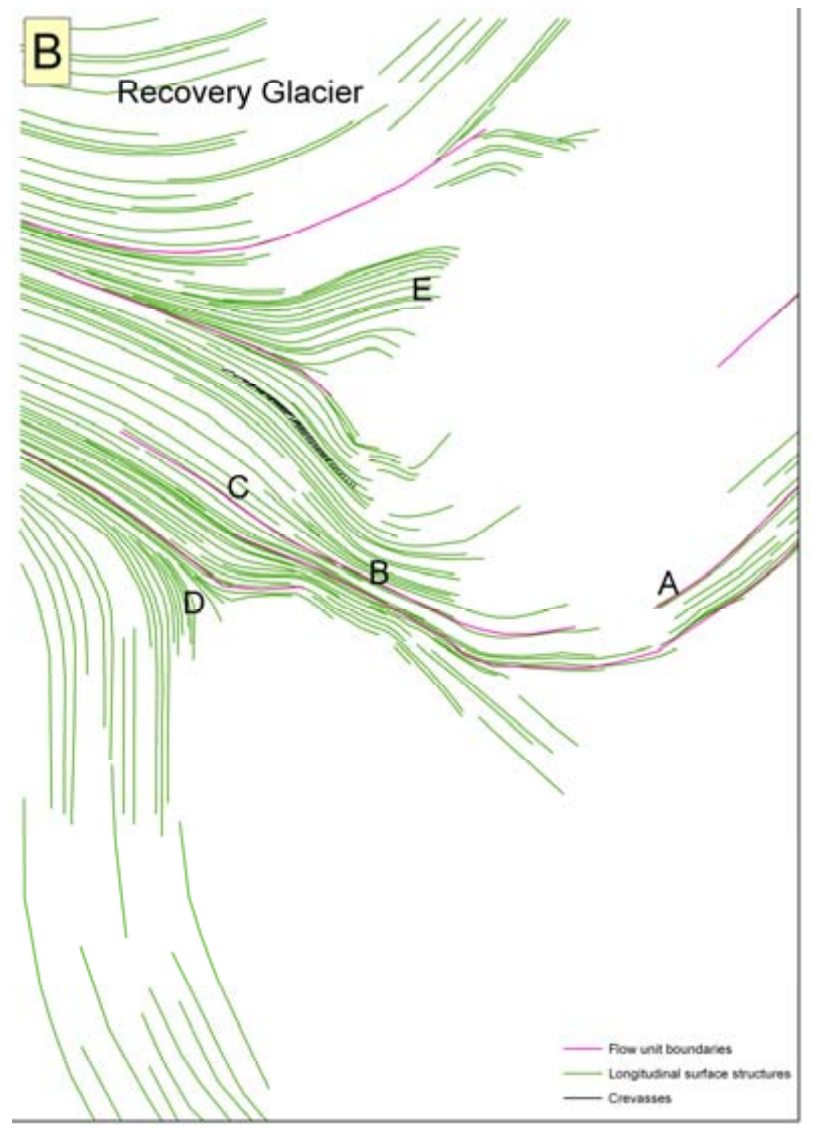

Fig. 5b. Interpretation of key surface structures. Point A indicates disruption to otherwise persistent longitudinal surface structures in a crevassed zone. Points $\mathrm{B}$ and $\mathrm{C}$ indicate converging and diverging longitudinal surface structures respectively as the glacier flows through a narrow constriction. Point D indicates the zone of convergence between Recovery Glacier and Support Force Glacier. Point $\mathrm{E}$ indicates the initiation of longitudinal surface structures at the base of an inferred icefall.

2. At glacier confluences, larger glaciers tend to "pinch out" longitudinal structures where they meet smaller tributary glaciers (Fig. 2).

3. Longitudinal structures can be followed without interruption from cirque headwalls as far as glacier snouts (Figs. 2 and 3). In some cases, the continuity of longitudinal structures survives the development of other glacier structures e.g. in heavily crevassed zones (Fig. 4).

4. Longitudinal structures sometimes, but not always, intensify in zones of lateral compression, for example at valley constrictions (Fig. 5).

5. Longitudinal structures are more closely spaced at flowunit boundaries than away from flow-unit boundaries (Fig. 7). 


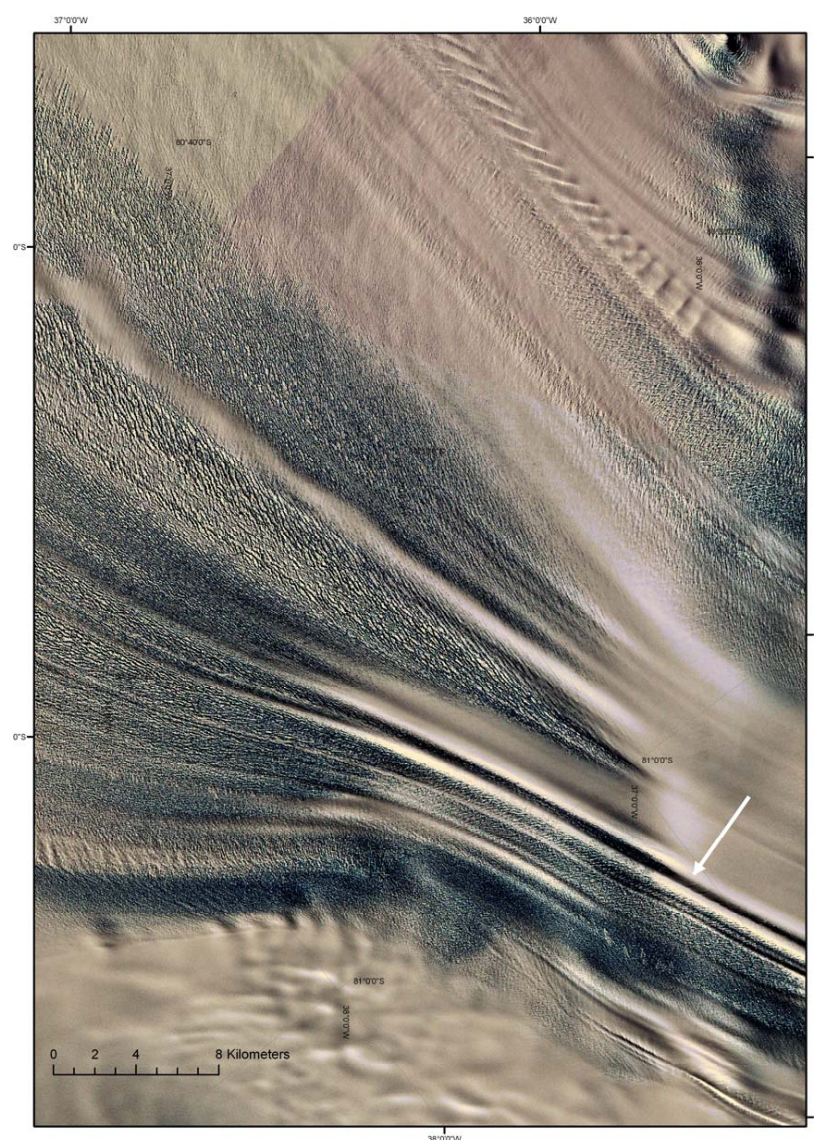

Fig. 6. Close up of portion of tributary glacier to Recovery Glacier from LIMA showing detail of longitudinal structures, including their trough morphology (arrowed). Location of figure is marked on Fig. 5.

6. Longitudinal surface structures are most prominent where ice flow is convergent but they can also be maintained where flow diverges, for example where there is lateral spreading of ice flow onto an ice shelf (Fig. 4).

7. Longitudinal surface structures start abruptly, particularly behind bedrock obstacles such as nunataks (Fig. 3), in cirque basins (Figs. 2 and 4), at glacier margins (Fig. 4), below steep sections of glaciers (Fig. 4) and in ice-stream onset zones (Fig. 5). In these situations the longitudinal structures are marked by linear troughs or depressions on the ice surface (Fig. 6).

8. Longitudinal surface structures can turn $>90$ degrees without interruption and without apparent evidence of increased lateral compression (Fig. 3).

9. Longitudinal surface structures are sometimes (but rarely) associated with surface debris such as lateral and medial moraines (Fig. 2). More commonly they are not associated with debris (Figs. 3, 4 and 5).

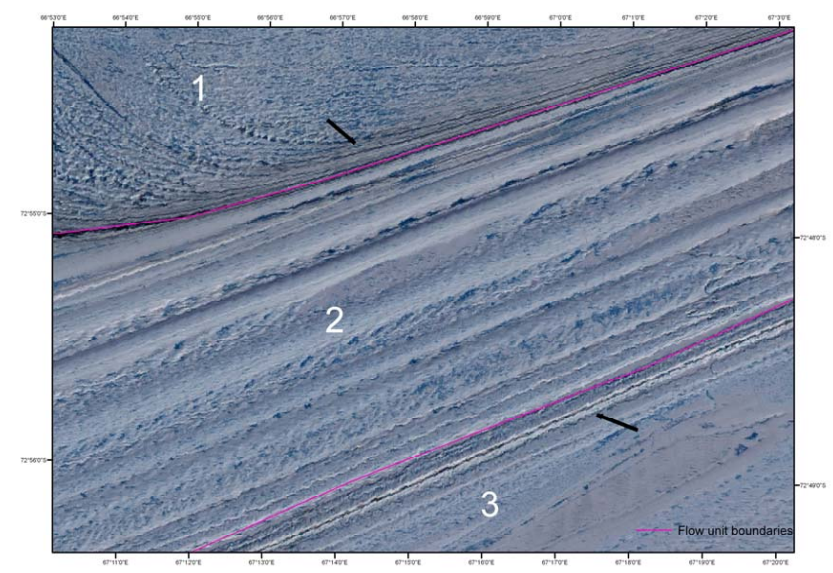

Fig. 7. Close up of part of the Lambert Glacier showing differences in spacing of longitudinal surface structures at flow-unit boundaries and away from flow-unit boundaries. Arrows indicate closely spaced longitudinal surface structures at the boundaries of flow units $1 \& 2$ and $2 \& 3$. These contrast with the longitudinal surface structures developed within flow unit 2 , inherited from further up-glacier, which are more widely spaced.

\section{Discussion}

Our analysis of the satellite images suggests that longitudinal surface structures (flowstripes) can develop in two main situations: (1) within glacier flow units and (2) where there is convergent flow around nunataks or at glacier confluence zones. The former type has previously been explained by the effects of basal perturbations on ice-stream surfaces (Gudmundsson et al., 1998) and is therefore not considered further here. The second type, consisting of features that form where there is convergent flow around nunataks or at flowunit boundaries/glacier confluence zones, have not been adequately explained by existing mechanisms so we now concentrate on mechanisms by which these features might form.

Where longitudinal surface structures start abruptly, for example in accumulation basins, below steep sections, in the upper reaches of glaciers, or at glacier margins where there is input of snow and ice from the surrounding slopes, these features are formed in zones of rapid longitudinal extension. In these areas longitudinal extension exceeds transverse compression. We therefore propose that longitudinal surface structures can be explained by extensional flow (Fig. 8). The confluence area of two glaciers or flow units is often characterised by strong transverse convergence and a concomitant longitudinal extension in the horizontal plane (Figs. 6 and 7). The longitudinal extension is a simple consequence of the geometrical configuration of a confluence area. At the junction point - the point at the margin where the two converging glaciers first make contact - the slowly moving ice forming the marginal zones of both tributaries is accelerated away from the margin towards the centre of the confluence area where velocities are generally much higher than at the 


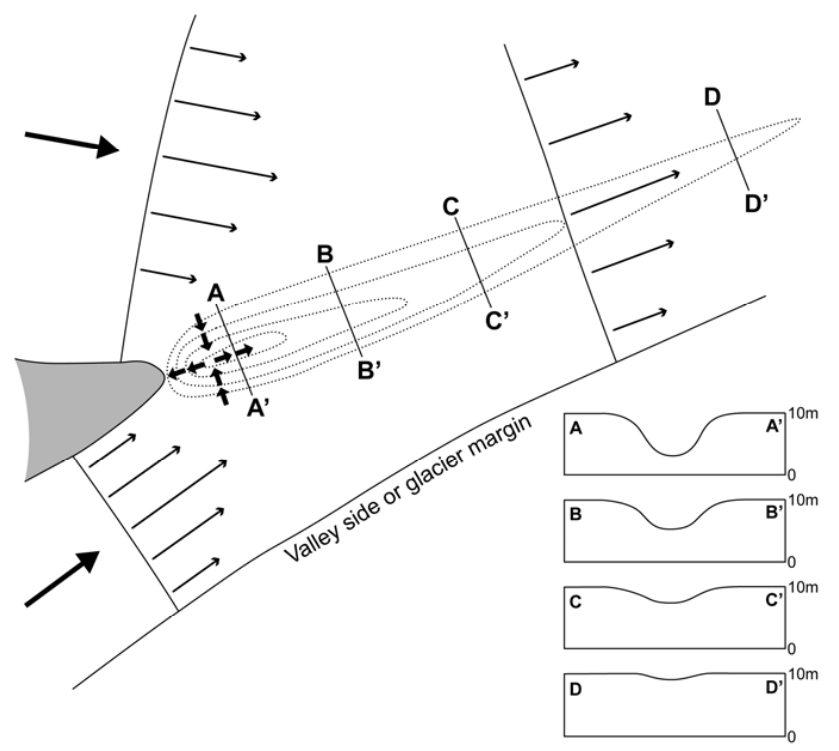

Fig. 8. Schematic illustration of the formation of longitudinal surface structures at the confluence of two glaciers. The confluence area is marked by strong transverse convergence and a concomitant longitudinal extension in the horizontal plane. This creates a surface depression or hollow at the confluence, indicated here by the contour lines (dashed lines). Cross-profiles A-A' to D-D' indicate the expected ice-surface morphology. The downstream extent of the flow stripe is determined by the time it takes the hollow to be filled in by transverse compression, and the distance travelled over the same time. The hollow can also be filled in by drifting snow or by differential ablation.

margins. Consequently, the ice is stretched in the horizontal direction. As the ice is pulled away from the junction point, a surface depression is formed. Mass conservation is attained once the depression has reached a size where ice flux sideways towards the depression balances the downstream flux of ice away from the depression. This longitudinal extension successfully explains the "ridge and trough" form of longitudinal surface structures on the ice surface (Figs. 6 and 7).

Because the formation of a surface trough in the vicinity of the junction point is a straightforward consequence of the mechanics of glacier flow in confluence areas, we expect this process to operate at all confluence areas. However, other surface processes, such as differential ablation and spatially variable snow deposition, can sometime mask the effect of ice flow on surface geometry. On the Amery Ice Shelf in front of the Lambert Glacier, where mean annual snow accumulation is $\sim 1.2 \mathrm{ma}^{-1}$ (Budd et al., 1982), for example, longitudinal surface structures are progressively masked downice by surface snow (Fig. 2a). In confluence areas located below the equilibrium line it is common to observe a medial moraine, caused by differential ablation processes, rising above the surrounding ice surface, rather than the otherwise expected elongated surface depression. In the Antarctic, because most confluence areas are well above the equilibrium line (although we note that ablation does occur; for example on Taylor Glacier where the maximum ablation is estimated to be $-0.44 \mathrm{ma}^{-1}$ w.e. at the snout; Robinson, 1984), the surface topography is not affected by differential ablation so these features can persist for many tens of kilometres downice. Examples of confluence areas where this process can be expected to operate are regions downstream of nunataks and smaller tributaries feeding sideways into fast-flowing ice streams.

The surface morphology of the flow stripes generated at junction points differs sharply from those generated by ice flow over basal topographic perturbations (Fig. 7). Numerical modelling by Gudmundsson (1997) shows that the transverse extent of the surface troughs formed at junction points is limited and does not scale with mean ice thickness. This agrees favourably with our observations that flow stripes originating from junction points are narrow and their transverse width bears no apparent relationship to estimated mean ice thickness or the width of converging tributaries.

The transverse width of flow stripes generated in reaction to ice flow over bedrock protuberances is, on the other hand, determined by the basal-to-surface transfer characteristics of flowing ice. This is discussed in some detail in Gudmundsson et al. (1998), where it is argued that flow stripes of this type can only form when the (slip) ratio between basal velocity and the deformational velocity is much larger than unity. Furthermore, because the transfer amplitudes are small $(<0.1)$ over wavelengths comparable and shorter than the ice thickness, no narrow flow stripes can be formed through this mechanism. This fits very well with our observations from satellite images, since we find that flow stripes formed in this manner are generally wider than those formed at glacier confluences by extensional flow.

The hypothesis that flowstripes are the surface expression of vertical sheets of changed ice fabric (Hulbe and Whillans, 1997) is testable because this hypothesis predicts that the surface expression of an aligned-crystal band should change with time and down-glacier motion. The portion of the band exposed at the ice surface should narrow due to progressive over-riding as adjacent ice is pushed up-dip (see their Fig. 9). We would therefore expect these bands of changed ice fabric to narrow progressively in a down-ice direction. However, we do not see evidence of this down-ice narrowing of bands even on very long glacier systems such as the Lambert Glacier (e.g. Fig. 2b).

\section{Conclusions and outlook}

Longitudinal surface structures are common features on the surface of Antarctic glaciers and ice streams. These flow stripes are streak lines. They form in at least two principal settings: within fast-flowing glaciers as a response to localized bed undulations and at the confluence of glacier tributaries as a result of strong transverse convergence and a 
concomitant longitudinal extension in the horizontal plane. The width of the first type is comparable to or a few times the mean ice thickness, but the second type are typically narrower, more persistent and more clearly defined on the ice surface. We have presented a simple conceptual model explaining how these features form through longitudinal extension. Further numerical modelling is required to test this simple conceptual model.

Acknowledgements. Neil Glasser was provided with no-cost access to ASTER images from NASA as a NASA-supported researcher. Landsat images were taken from the Landsat Image Mosaic of Antarctica (LIMA).

Edited by: C. O'Cofaigh

\section{References}

Appleby, J. R., Brook, M. S., Vale, S. S., and Macdonald-Creevey, A. M.: Structural glaciology of a temperate maritime glacier: Lower Fox Glacier, New Zealand, Geogr. Ann., 92A, 451-467, 2010.

Budd, W. F., Corry, M. J., and Jacka, T. H.: Results from the Amery Ice Shelf project, Ann. Glaciol., 3, 36-41, 1982.

Campbell, I., Jacobel, R., Welch, B., and Pettersson, R.: The evolution of surface flow stripes and stratigraphic folds within Kamb Ice Stream: why don't they match?, J. Glaciol., 54, 421-427, 2008.

Casassa, G. and Brecher, H. H.: Relief and decay of flow stripes on Byrd Glacier, Antarctica, Ann. Glaciol., 17, 255-261, 1993.

Casassa, G., Jezek, K. C., Turner, J., and Whillans, I. M.: Relict flow stripes on the Ross Ice Shelf, Ann. Glaciol., 15, 132-138, 1991.

Crabtree, R. D. and Doake, C. S. M.: Flow Lines on Antarctic Ice Shelves, Polar Rec., 20, 31-37, 1980.

Fahnestock, M. A., Scambos, T. A., Bindschadler, R. A., and Kvaran, G.: A millennium of variable ice flow recorded by the Ross Ice Shelf, Antarctica, J. Glaciol., 46, 652-664, 2000.

Glasser, N. F. and Scambos, T. A.: A structural glaciological analysis of the 2002 Larsen B Ice Shelf collapse, J. Glaciol., 54, 3-16, 2008.

Goodsell, B., Hambrey, M. J., Glasser, N. F., Nienow, P., and Mair, D.: The Structural Glaciology of a Temperate Valley Glacier: Haut Glacier d'Arolla, Valais, Switzerland, Arct. Antarct. Alp. Res., 37, 218-232, 2005.

Gudmundsson, G. H: Ice deformation at the confluence of two glaciers investigated with conceptual map-plane and flowline models, J. Glaciol., 43, 537-547, 1997.

Gudmundsson, G. H., Raymond, C. F., and Bindschadler, R.: The origin and longevity of flow-stripes on Antarctic ice streams, Ann. Glaciol., 27, 145-152, 1998.
Hambrey, M. J.: The origin of foliation in glaciers: evidence from some Norwegian examples, J. Glaciol., 14, 181-185, 1975.

Hambrey, M. J.: Foliation, minor folds and strain in glacier ice, Tectonophysics, 39, 397-416, 1977.

Hambrey, M. J. and Dowdeswell, J. A.: Flow regime of the Lambert Glacier-Amery Ice Shelf system, Antarctica: structural evidence from Landsat imagery, Ann. Glaciol., 20, 401-406, 1994.

Hambrey, M. J. and Glasser, N. F.: The role of folding and foliation development in the genesis of medial moraines: examples from Svalbard glaciers, J. Geol., 111, 471-485, 2003.

Hooke, R. Le B. and Hudleston, P. J.: Origin of foliation in glaciers, J. Glaciol., 20, 285-299, 1978.

Hulbe, C. L. and Fahnestock, M. A.: West Antarctic ice-stream discharge variability: mechanism, controls and pattern of grounding-line retreat, J. Glaciol., 50, 471-484, 2004.

Hulbe, C. L. and Fahnestock, M. A.: Century-scale discharge stagnation and reactivation of the Ross ice streams, West Antarctica, J. Geophys. Res., 112, F03S27, doi:10.1029/2006JF000603, 2007.

Hulbe, C. L. and Whillans, I. M.: Weak bands within Ice Stream B, West Antarctica, J. Glaciol., 43, 377-386, 1997.

Jacobel, R. W., Gades, A. M., Gottschling, D. L., Hodge, S. M., and Wright, D. L.: Interpretation of radar-detected internal layer folding in West Antarctic ice streams, J. Glaciol., 39, 528-537, 1993.

Jacobel, R. W., Scambos, T. A., Raymond, C. F., Gades, A. M.: Changes in the configuration of ice-stream flow from the West Antarctic Ice Sheet, J. Geophys. Res., 101, 5499-5504, 1999.

Merry, C. J. and Whillans, I. M.: Ice-flow features on Ice Stream B, Antarctica, revealed by SPOT HRV imagery, J. Glaciol., 39, 515-527, 1993.

Raup, B. H., Scambos, T. A., and Haran, T.: Topography of streaklines on an Antarctic ice shelf from photoclinometry applied to a single Advanced Land Imager (ALI) image, IEEE T. Geosci. Remote, 43, 736-742, 2005.

Raymond, C. F.: Shear margins in glaciers and ice sheets, J. Glaciol., 42, 90-102, 1996.

Reynolds, J. M. and Hambrey, M. J.: The structural glaciology of George VI Ice Shelf, Antarctic Peninsula, Brit. Antarct. Surv. B., 79, 79-95, 1988.

Robinson, P. H.: Ice dynamics and thermal regime of Taylor Glacier, South Victoria Land, Antarctica, J. Glaciol., 30, 153160, 1984.

Swithinbank, C., Brunt, K., and Sievers, J.: A glaciological map of Filchner-Ronne Ice Shelf, Antarctica, Ann. Glaciol., 11, 150$155,1988$.

Whillans, I. M. and Van der Veen, C. J.: The role of lateral drag in the dynamics of Ice Stream B, Antarctica, J. Glaciol., 43, 231237, 1997.

Wuite, J. and Jezek, K. C.: Evidence of past fluctuations on Stanscomb-Wills Ice Tongue, Antarctica, preserved by relict flow stripes, J. Glaciol., 55, 239-244, 2009. 